\title{
Observing the Changing Health of Circumpolar Peoples
}

\author{
Kue Young, ${ }^{1}$ Susan Chatwood ${ }^{2}$ and Peter Bjerregaard ${ }^{3}$
}

(Received 26 May 2014; accepted in revised form 26 August 2014)

\begin{abstract}
This paper describes the elements involved in observing health in circumpolar regions, the status of current observation systems, and gaps within the monitoring networks. The aim is to provide a starting point for discussion of the role that health monitoring might play in developing Arctic observing networks and initiatives that aim to improve the health status of circumpolar populations. It is hoped that this background information will provide direction for further development of monitoring systems and networks through supporting data capture, analysis, and uptake.
\end{abstract}

Key words: Arctic; statistical systems; observatory; health monitoring

RÉSUMÉ. Cet article décrit les éléments qui entrent en jeu en matière d'observation de la santé dans les régions circumpolaires, de même que l'état des systèmes d'observation actuels et les écarts qui existent au sein des réseaux de surveillance. L'objectif consiste à fournir un point de départ pour une discussion sur le rôle que pourrait jouer la surveillance de la santé dans les initiatives et les réseaux mis en place dans l'Arctique dans le but d'améliorer l'état de santé des populations circumpolaires. On espère que ces renseignements généraux serviront de fondement à la mise au point d'autres systèmes et réseaux de surveillance grâce à la capture de données pertinentes, à leur analyse et à leur prise en charge.

Mots clés : Arctique; systèmes statistiques; observatoire; surveillance de la santé

Traduit pour la revue Arctic par Nicole Giguère.

\section{INTRODUCTION}

A variety of existing networks observe and monitor changes in the marine, terrestrial, atmospheric, and human dimensions in the Arctic. The International Polar Year of 2007-08 for the first time put the human dimension on an equal footing with the others. Observing health is clearly within the human dimension. However, health observations have certain unique requirements that distinguish them from those of other observing networks and systems that are based primarily on the physical sciences. This paper highlights the importance of an observing network focused on human health.

\section{WHAT'S SO DIFFERENT ABOUT OBSERVING HEALTH?}

Observing human health requires direct involvement with people and their communities. Data may be obtained by using a questionnaire, by sampling various body tissues or fluids for specific tests, and by taking measurements on the entire body or specific parts of the body. Contextual or environmental data relevant to health, which do not require contact with individuals, could also be collected. Finally, observations on individuals must be aggregated to the population level in order to discern patterns and trends and make comparisons across space and time.

Because observing health requires the participation of individuals at the various levels into which individuals are organized (families, communities, regions, and nations), there are important ethical, administrative, and political considerations. At the level of families and communities, it is important to accommodate cultural aspects, and numerous models that promote the co-management of health research projects have emerged. At the individual level, privacy and confidentiality are prime concerns. Scientific objectivity may occasionally conflict with efforts not to harm or stigmatize groups or individuals. Collecting information from individuals poses unique logistical challenges. Individuals need to be found, gathered, persuaded, and often compensated - if not in monetary terms, at least with the promise of potential benefits to themselves, their communities, or society at large. On the positive side, some health information is routinely collected as part of the functioning of different levels of governments (so-called secondary data) and thus requires little time or cost to retrieve, organize, and analyze.

While the dissemination of research findings in peerreviewed scientific journals is the standard found in any

\footnotetext{
${ }^{1}$ Corresponding author: School of Public Health, University of Alberta, 11405-87 Avenue, Edmonton, Alberta T6G 169, Canada; Kue.young@ualberta.ca

${ }^{2}$ Institute for Circumpolar Health Research, PO Box 11050, Yellowknife, Northwest Territories X1A 3X7, Canada

${ }^{3}$ National Institute of Public Health, Øster Farimagsgade 5, Copenhagen K, DK-1399, Denmark

(C) The Arctic Institute of North America
} 
discipline, the translation of these findings into improved clinical guidelines, health services delivery, and policy development is more complex. Knowledge produced by researchers needs to be interpreted, disseminated, and transferred to decision makers, and while this task is poorly and unevenly carried out across the Arctic, it must be an integral component of any circumpolar health observing network.

\section{WHO ARE CIRCUMPOLAR PEOPLES?}

People live in communities that belong to some political and administrative divisions of nation-states, and health data are usually collected, aggregated, and reported by such political-administrative units. Therefore, for the purpose of observing the health of populations, it is not appropriate to define the boundaries of "Arctic" or "circumpolar" on the basis of geophysical or climatic criteria. We have identified 27 northernmost regions of the eight member states of the Arctic Council (including their self-governing territories) to constitute the target populations of a health-observing network (Table 1). These regions vary greatly in terms of physical terrain and climate (Young et al., 2012). A drawback of such an approach is that the boundaries of sub-national entities often change - these units could be amalgamated, subdivided, or even abolished altogether. In Canada, for example, the new territory Nunavut was created in 1999 from a division of the Northwest Territories. In 2007 the Taymyr, Evenkia, and Koryak Autonomous Okrugs (AOs) ceased to be distinct federal "subjects" (i.e., regions) of the Russian Federation and were absorbed into larger administrative units. Data that were once available for those AOs are no longer reported.

Another important issue is the ethnic diversity of circumpolar peoples (Bjerregaard et al., 2004; Young and Bjerregaard, 2008). A health-observing network ideally should be able to separate out health data for the different ethnic groups that reside within a particular territory. In the Arctic, this usually means Indigenous/Native/Aborigi$\mathrm{nal} /$ and numerically small people vs all others, and within the former group, further subdivisions such as Inuit, Dene/ Athabaskan, Sami, Aleut, Chukchi, and Nenets. The proportion of Indigenous people varies across regions, from $0 \%$ to $90 \%$. The capability to provide this level of detail varies greatly across the Arctic states, and it has also changed (usually deteriorated) over time. Clearly, some degree of separation by broad categories is desirable for any Arctic health-observing network. It is also desirable to classify data in other ways, by age, gender, or socioeconomic position. The capability to make those distinctions again varies considerably, depending on the type of variable.

\section{WHY DOES THEIR HEALTH NEED OBSERVING?}

The mere existence of data does not mean that they need to be pursued. Conversely, some data that currently do not
TABLE 1. The 27 northern regions of the eight Arctic states.

\begin{tabular}{ll}
\hline \hline Country & Region \\
\hline United States & Alaska \\
Canada & Yukon \\
& Northwest Territories \\
Denmark & Nunavut \\
& Greenland \\
Iceland & Faroe Islands \\
Norway & Nordland \\
& Troms \\
Sweden & Finnmark \\
& Västerbotten \\
Finland & Norrbotten \\
& Oulu \\
Russian Federation & Lappi \\
& Murmansk Oblast \\
& Kareliya Republic \\
& Arkhangelsk Oblast \\
& Nenets AO \\
& Komi Republic \\
& Yamalo-Nenets AO \\
Khanty-Mansi AO \\
Taymyr AO \\
& Evenkia AO \\
& Sakha Republic \\
& Magadan Oblast \\
& Koryak AO \\
Chukotka AO \\
\hline
\end{tabular}

\footnotetext{
${ }^{1}$ In 2010, Finland replaced the old administrative unit (lääni) with the regional state administrative agency (aluehallintovirasto or AVI), but the boundaries of Oulu (now called Pohjois-Suomi) and Lappi, the two northernmost regions, did not change.

${ }^{2} \mathrm{AO}=$ autonomous okrug.

${ }^{3}$ In 2007, the Taymyr, Evenkia, and Koryak AOs were absorbed into the Krasnoyarsk kray and Kamchatka kray.
}

exist are essential. Health data should serve some purpose. In most jurisdictions, health monitoring or surveillance (which are terms more familiar to public health professionals than "observing") is an integral part of the mandated activities and functions of the health care system, particularly what is known as "public health." Data are needed to describe, assess, evaluate, and predict the health of the population. They are needed to identify gaps in service delivery, provide help in planning programs, and inform policy development.

For the Arctic, besides these standard functions of health data, there is also the urgent task of tracking the health impacts of the rapidly changing physical and social environments, whether these changes are induced by or associated with climate change, resource development, or political evolution (Chatwood et al., 2012).

Health has not been a major focus of the Sustaining Arctic Observing Networks (SAON). Only two of the 28 officially endorsed networks, projects, and programs listed on its website (www.arcticobserving.org) are primarily healthoriented. SAON offers the potential to link vastly different data systems across disparate scientific disciplines and enables important scientific and policy questions to be 
addressed. To date, health has not been explicitly linked to the other data systems. For example, can one establish a causal chain from climate change, through wildlife population, to food insecurity, by linking and correlating data on precipitation, hunting harvests, and nutrient intake across national and regional boundaries?

\section{WHAT ASPECTS OF HEALTH CAN BE OBSERVED NOW?}

All Arctic states have well-developed national statistical systems that routinely collect important data relevant to health. A long tradition of population-based health research in these countries has also generated substantial amounts of data. At the national level, there is no serious problem. It is at the regional level- the 27 northernmost politicaladministrative divisions of the Arctic states-for which comprehensive and continuous health data series are not consistently available.

Three current projects can be considered prototypes of Arctic health observing networks. Two are focused on specific health concerns, while the third is broad-based and covers a range of indicators.

1) The Arctic Monitoring and Assessment Programme (AMAP). AMAP has had a Human Health Assessment Group (HHAG) since 1991 and has been collecting, analyzing, and reporting the human health effects of various environmental contaminants. Human subjects have been sampled in selected sites across the Arctic, and a variety of biomarkers have been analyzed. In addition to various health chapters in AMAP assessment reports, major health reports from AMAP-HHAG include Human Health in the Arctic 2002 (AMAP, 2003) and Human Health in the Arctic 2009 (AMAP, 2009).

2) International Circumpolar Surveillance of Infectious Diseases (ICS). Begun in 1998 under the leadership of the Arctic Investigations Program (a branch of the U.S. Centers for Disease Control and Prevention located in Anchorage, Alaska), ICS is a collaboration of public health departments and laboratories from several circumpolar countries. It collects standardized and laboratory-confirmed cases of tuberculosis and several invasive bacterial diseases, together with relevant clinical information. ICS is a project endorsed by the Arctic Council and supported financially by the various collaborating agencies (Parkinson et al., 2008; Zulz et al., 2009).

3) Circumpolar Health Observatory (CircHOB). Launched in 2009 as a project endorsed by the Arctic Council, CircHOB is a web-based, interactive resource that presents freely downloadable tables and maps of a series of health indicators for all northern regions. (http://circhob. circumpolarhealth.org). The majority of these data are derived from publicly available sources (Young et al., 2010). CircHOB currently monitors the following categories of health indicators:

- Population: size, age and sex distributions, density;

- Fertility: crude birth rate, age-specific and total fertility rates, distribution of live births by age of mother, sex ratio;

- Mortality: crude death rate, age-sex-specific mortality rates, life expectancy at birth, infant mortality rate;

- Reproductive outcomes: perinatal mortality rate, distribution of live births by birth weight and gestational age;

- Disease incidence: incidence of cancer (by site), tuberculosis, and gonorrhea;

- Socioeconomic conditions: Gross Domestic Product, tertiary education;

- Health-related behaviours: smoking prevalence;

- Health care resources: distribution of health workforce (physicians, dentists, and nurses) and hospital beds, per capita health expenditures.

\section{WHAT ARE THE SOURCES OF HEALTH DATA?}

A sustainable Arctic health observing network should access, retrieve, and collate data from a variety of data sources, some of which are ongoing, with data routinely collected by different government agencies, health boards, and communities. Some cover the entire target population, while others are sporadic or periodic studies that cover only selected sites: population registries, censuses and intercensal estimates, vital statistics, disease registries, health care utilization databases, population health surveys, and special research studies.

Studies and surveys conducted as international collaborative projects using standardized and comparable protocols are important sources of data. Examples include the various health surveys conducted among Inuit in Alaska, Canada, and Greenland in the 1990s and 2000s (Bjerregaard et al., 2003; Young et al., 2007) and also the reviews of cancer incidence among the Inuit and other circumpolar Indigenous populations (Circumpolar Inuit Cancer Review Working Group, 2008a, b). Plans are also underway to conduct an international Inuit cohort study to follow up on the baseline surveys.

\section{WHY ARE IMPROVEMENTS NEEDED?}

Health data must be comparable across national and regional boundaries: likes must be compared with likes. For most health indicators, there is broad international agreement on definitions and criteria; however, others are dependent on a particular country's political, social, and healthcare systems. For example, if health care personnel are trained, regulated, and registered differently or have 
different functions, even if they share the same name (e.g., "doctor" or "nurse") in English translation, then comparing their numbers and frequency per capita can be problematic. Much theoretical and conceptual groundwork remains to be done for circumpolar standardization.

Large data gaps exist for areas that are not being covered by the three existing networks. Important categories of health indicators that should also be monitored include the following:

- Health-related behaviours: alcohol and drug use, physical activity, sexual behaviour, nutrition and diet;

- Physiological measurements: blood pressure, obesity, plasma cholesterol, glucose;

- Measurements of mental health and well-being;

- Use of health care providers: hospital and primary care;

- Performance of the health system.

Special efforts need to be directed at developing indicators that reflect the cultural understanding of Indigenous people regarding wellness, which usually extends beyond the biomedical or psychosocial to incorporate the spiritual dimension. Electronic medical records exist in some but not all regions, and their development and standardization will facilitate and enhance health and health care monitoring considerably.

\section{WHAT SHOULD A SUSTAINABLE ARCTIC HEALTH OBSERVING NETWORK BE LIKE?}

A sustainable Arctic health-observing network need not be started from scratch but can build on existing networks and activities. It should be an international collaborative health information system, involved in systematic, standardized, and consistent collection and analysis of valid and comparable health data. It is important for this network to be population-based and to cover all northern regions in all circumpolar countries. Data gaps will undoubtedly exist, but identifying such gaps will also spur on international collaboration to fill them. The coverage of the network should be broad, as it should monitor trends and patterns in health status, health determinants, and health care. Although monitoring is an important scientific activity in its own right, the network also exists to provide an ongoing, timely, and sustainable knowledge base and analytical support for decision makers, service providers, academic researchers, and consumers. Such a network will provide opportunities to promote training and research in population health and health systems and enhance partnerships and collaborations among circumpolar communities, regions, and countries. The health sciences are far from a monolithic scientific discipline, and a health-observing network should adopt mixed methods and integrate community-based observations with epidemiological tools and techniques and "hard" quantitative data. Such cross-disciplinary orientation is particularly important when addressing priority areas such as environmental impacts.

\section{CONCLUSIONS}

The Arctic is rapidly changing. Health monitoring is an integral and essential component of any international collaborative effort to develop observing networks. A circumpolar health observing network needs to be comprehensive and inclusive of different scientific approaches. Building on existing initiatives, it should promote new developments in data sharing and storage, improve the quality of data collection and analysis, and expedite the application of findings to create better circumpolar health systems.

\section{REFERENCES}

AMAP (Arctic Monitoring and Assessment Programme). 2003. AMAP assessment 2002: Human health in the Arctic. Oslo: AMAP.

http:/www.amap.no/documents/doc/amap-assessment-2002human-health-in-the-arctic/95

- 2009. AMAP assessment 2009: Human health in the Arctic. Oslo: AMAP.

http:/www.amap.no/documents/doc/amap-assessment-2009human-health-in-the-arctic/98

Bjerregaard, P., Dewailly, E., Young, T.K., Blanchet, C., Hegele, R.A., Ebbesson, S.E.O., Risica, P.M., and Mulvad, G. 2003. Blood pressure among the Inuit (Eskimo) populations in the Arctic. Scandinavian Journal of Public Health 31(2):92-99. http://dx.doi.org/10.1080/14034940210133924

Bjerregaard, P., Young, T.K., Dewailly, E., and Ebbesson, S.O.E. 2004. Indigenous health in the Arctic: An overview of the circumpolar Inuit population. Scandinavian Journal of Public Health 32(5):390-395. http://dx.doi.org/10.1080/14034940410028398

Chatwood, S., Bjerregaard, P., and Young, T.K. 2012. Global health - a circumpolar perspective. American Journal of Public Health 102(7):1246-1249.

http://dx.doi.org/10.2105/AJPH.2011.300584

Circumpolar Inuit Cancer Review Working Group. 2008a. Cancer among the circumpolar Inuit, 1989-2003. I. Background and methods. International Journal of Circumpolar Health 67(5):396-407.

http://www.circumpolarhealthjournal.net/index.php/ijch/ article/view/18348

- 2008b. Cancer among the circumpolar Inuit, 1989-2003. II. Patterns and trends. International Journal of Circumpolar Health 67(5):408-420.

http://www.circumpolarhealthjournal.net/index.php/ijch/ article/view/18349 
Parkinson, A.J., Bruce, M.G., Zulz, T., and the International Circumpolar Surveillance Steering Committee. 2008. International Circumpolar Surveillance, an Arctic network for the surveillance of infectious diseases. Emerging Infectious Diseases 14(1):18-24. http://dx.doi.org/10.3201/eid1401.070717

Young, T.K., and Bjerregaard, P., eds. 2008. Health transitions in Arctic populations. Toronto: University of Toronto Press.

Young, T.K., Bjerregaard, P., Dewailly, E., Risica, P.M., Jørgensen, M.E., and Ebbesson S.E.O. 2007. Prevalence of obesity and its metabolic correlates among the circumpolar Inuit in 3 countries. American Journal of Public Health 97(4):691 - 695. http://dx.doi.org/10.2105/AJPH.2005.080614
Young, T.K., Chatwood, S., and Rawat, R. 2010. Data brief from the Circumpolar Health Observatory: Introduction and population. International Journal of Circumpolar Health 69(4):404-408.

http://www.circumpolarhealthjournal.net/index.php/ijch/ article/view/17667

Young, T.K., Rawat, R., Dallmann, W., Chatwood, S., and Bjerregaard, P., eds. 2012. Circumpolar health atlas. Toronto: University of Toronto Press.

Zulz, T., Bruce, M.G., and Parkinson, A.J. 2009. International Circumpolar Surveillance: Prevention and control of infectious diseases: 1999-2008. Circumpolar Health Supplements 2009(4). Oulu: International Association of Circumpolar Health Publishers.

http://www.circumpolarhealthjournal.net/public/journals/32/ chs/CHS_2009_4.pdf 